\title{
Fine-scale habitat partitioning of Chilean and Peale's dolphins and their overlap with aquaculture
}

\begin{tabular}{|c|c|}
\hline Journal: & Aquatic Conservation: Marine and Freshwater Ecosystems \\
\hline Manuscript ID & AQC-18-0317.R1 \\
\hline Wiley - Manuscript type: & Supplement Article \\
\hline $\begin{array}{r}\text { Date Submitted by the } \\
\text { Author: }\end{array}$ & 15-Dec-2018 \\
\hline Complete List of Authors: & $\begin{array}{l}\text { Heinrich, Sonja; University of St Andrews, Sea Mammal Research Unit, } \\
\text { KY16 8LB } \\
\text { Genov, Tilen; University of St Andrews, Sea Mammal Research Unit, } \\
\text { KY16 8LB } \\
\text { Fuentes Riquelme, Marjorie; Yaqu Pacha Chile, Gorbea 2550, off } 313 \\
\text { Hammond, Philip; University of St Andrews, Sea Mammal Research Unit, } \\
\text { KY18 6LB }\end{array}$ \\
\hline $\begin{array}{l}\text { Broad habitat type } \\
\text { (mandatory) select 1-2: }\end{array}$ & coastal < Broad habitat type \\
\hline $\begin{array}{l}\text { General theme or application } \\
\text { (mandatory) select } 1-2 \text { : }\end{array}$ & $\begin{array}{l}\text { habitat mapping < General theme or application, conservation evaluation } \\
<\text { General theme or application }\end{array}$ \\
\hline $\begin{array}{l}\text { Broad taxonomic group or } \\
\text { category (mandatory, if } \\
\text { relevant to paper) select } 1-2 \text { : }\end{array}$ & mammals < Broad taxonomic group or category \\
\hline $\begin{array}{l}\text { Impact category (mandatory, } \\
\text { if relevant to paper) select } 1- \\
2:\end{array}$ & aquaculture < Impact category \\
\hline
\end{tabular}

\section{SCHOLARONE ${ }^{\text {m }}$ \\ Manuscripts}




\title{
Fine-scale habitat partitioning of Chilean and Peale's dolphins and their overlap with aquaculture
}

\author{
Sonja HEINRICH ${ }^{1}$, Tilen GENOV ${ }^{1}$, Marjorie FUENTES RIQUELME², Philip S. HAMMOND ${ }^{1}$ \\ 1) University of St Andrews, Sea Mammal Research Unit, St Andrews, Fife KY16 8LB, UK \\ 2) Yaqu Pacha Chile, Gorbea 2550, off 313, Santiago, Chile
}

Correspondence:

Sonja Heinrich, sh52@st-andrews.ac.uk, 01334462628

University of St Andrews, Sea Mammal Research Unit, St Andrews, Fife KY16 8LB, UK

Running head: Habitat partitioning in coastal dolphins 


\section{Abstract:}

1. Predictive species distribution models (SDMs) have become powerful tools to determine habitat use patterns of mobile marine predators and their spatial overlap with potentially impacting anthropogenic activities.

2. This study used SDMs to investigate fine-scale habitat use patterns of two poorly known and broadly sympatric coastal delphinids, Chilean dolphins (Cephalorhynchus eutropia) and Peale's dolphins (Lagenorhynchus australis), and their spatial interactions with intense aquaculture farming activities in the Chiloé archipelago, southern Chile.

3. A long-term dataset (2002-2012) of boat-based dolphin sightings and concurrently in situ collected environmental and anthropogenic variables was analysed using binomial GAMs to investigate ecological drivers of each species' fine-scale distribution and to predict dolphin occurrence spatially.

4. Chilean dolphins preferred shallow ( $<30 \mathrm{~m}$ deep), turbid waters, close to shore $(<500$ m) and river mouths which often placed them in sheltered bays and channels used intensively by shellfish farms. Peale's dolphins were also found in shallow waters but occurred over a wider range of conditions along more open or exposed coastlines. Both species had to navigate extensive salmon and shellfish farming sites to transit between areas of important habitat.

5. Sightings and predicted occurrence maps showed a clear pattern of spatial habitat partitioning between species, which remained stable across the 11-year study period. The identification of important habitat for Chilean dolphins warrants the consideration of spatially explicit conservation measures to limit the potential effects of overlapping salmon and shellfish farming.

6. The observed differences in ecological plasticity of the two sympatric species should be considered when evaluating and mitigating the effects of environmental change and ongoing anthropogenic pressures on their nearshore habitat. The estimated species-environment relationships could also be used to predict where dolphin habitat and anthropogenic activities are most likely to overlap in other parts of the species' ranges. 
32 Keywords: predictive species distribution models, habitat use pattern, niche partitioning, Cephalorhynchus eutropia, Lagenorhynchus australis, aquaculture

\section{INTRODUCTION}

Where animals occur, what drives their distribution and how they use their habitat are some of the fundamental questions in ecology. Understanding how these patterns relate to the spatial distribution and extent of human activities, and how they might be affected by environmental change, is essential to conservation. Sympatric species may respond differently to environmental change and anthropogenic pressures, making the identification of species-

specific habitat use patterns a key requirement for effective conservation (Schaefer, Jetz, \& Böhning-Gaese, 2008; Silber et al., 2017).

Predictive species distribution models (Guisan \& Zimmermann, 2000), SDMs, have emerged as powerful tools to identify important habitats for species and for use in biodiversity conservation (Gregr, Baumgartner, Laidre, \& Palacios, 2013; Guisan et al., 2013; Lecours, 2017). SDMs can provide important ecological insights into species-environment relationships (Bräger, Harraway, \& Manly, 2003; Redfern et al., 2006) enable comparisons among species (Ingram, Walshe, Johnston, \& Rogan, 2007; Mannocci et al., 2014; Redfern et al., 2013), identify key areas and habitats (Esteban et al., 2014; Pérez-Jorge et al., 2015), and help predict where species might be most at risk from anthropogenic activities (Ashe, Noren, \& Williams, 2010; Redfern et al., 2013). They can also inform conservation and management by guiding spatially explicit mitigation actions such as the designation and management of marine protected areas (Bailey \& Thompson, 2009; Cañadas, Sagarminaga, De Stephanis, Urquiola, \& Hammond, 2005; IUCN-MMPATF, 2016). 
This study uses SDMs to investigate the habitat use patterns of two poorly known coastal delphinids, which occur in sympatry in southern Chile, one of the most intensively used marine aquaculture farming regions in the world (Bostock et al., 2010). The study species, Chilean dolphin (Cephalorhynchus eutropia, Gray 1846) and Peale's dolphin (Lagenorhynchus australis, Peale 1848), inhabit the nearshore waters of southern Chile, with Peale's dolphins also occurring over the continental shelf waters of the southern South Atlantic where they are sympatric with another Cephalorhynchus species (C. commersonnii, Lacépède 1804) (Heinrich, Elwen, \& Bräger, 2010).

Cephalorhynchus dolphins and Peale's dolphins are unusual amongst the delphinids in that their acoustic repertoire seems to consist only of narrow-band high frequency clicks which may be an adaptation to life in acoustically cluttered inshore waters (Götz, Antunes, \& Heinrich, 2010; Kyhn et al., 2010) and/or facilitates acoustic crypsis from their main potential predator, killer whales (Orcinus orca, Linnaeus 1758) (Morisaka \& Connor, 2007). Peale's dolphins are bigger than Chilean dolphins, and seem to show more ecological plasticity inhabiting a wider geographic and habitat range (Cipriano, 2018). Detailed information on diet is lacking for both species, but they are thought to forage on a variety of schooling and demersal fish and cephalopod species (Goodall, Norris, Galeazzi, Oporto, \& Cameron, 1988; Schiavini, Goodall, Lescrauwaet, \& Alonso, 1997). Both Chilean and Peale's dolphins seem to prefer nearshore shallow waters (Heinrich, 2006; Viddi, Hucke-Gaete, Torres-Florez, \& Ribeiro, 2010), but differ substantially in their encounter rates in southern Chile. Peale's dolphins are usually the most frequently sighted delphinid, whereas Chilean dolphins are rarely seen and appear to have a more patchy distribution concentrated in sheltered bays and channels (Aguayo-Lobo, Torres Navarro, \& Acevedo Ramírez, 1998; Viddi et al., 2010; ZamoranoAbramson, Gibbons, \& Capella, 2010). Both species are regularly sighted in the Chiloé 
79 archipelago where Peale's dolphins appear to outnumber small localized populations of

Chilean dolphins (Heinrich, 2006).

Since the early 1990s the Chiloé region has become the centre of Chile's lucrative salmonid and shellfish farming enterprises, leading to substantial increases in human population and infrastructure, and affecting the health of the coastal marine ecosystem (Buschmann et al., 2009; Buschmann, López, \& Medina, 1996; Sepúlveda, Arismendi, Soto, Jara, \& Farias, 2013). Potential direct effects of aquaculture farming on cetaceans include increased mortality due to entanglement in cage netting and ropes (Díaz López \& Bernal Shirai, 2007; Kemper \& Gibbs, 2001). However, most effects likely operate via multiple indirect and possibly synergistic pathways such as exclusion from important habitat, habitat degradation, food web alterations, noise pollution, contamination and spread of disease (Buschmann et al., 2009, 2012; Kemper et al., 2003; Markowitz, Harlin, Würsig, \& McFadden, 2004; Pearson, Vaughn-Hirshorn, Srinivasan, \& Würsig, 2012; Ribeiro, Viddi, Cordeiro, \& Freitas, 2007; Watson-Capps \& Mann, 2005). Fish farms can also affect dolphin habitat use patterns (Bonizzoni et al., 2014), because farmed fish or cage-associated wild fish can act as attractive food sources (Piroddi, Bearzi, \& Christensen, 2011).

This study uses a long-term dataset to model fine-scale habitat use of sympatric Chilean and Peale's dolphins in relation to environmental and anthropogenic variables in the Chiloé archipelago. It explores differences in habitat use patterns between the two species, identifies their key habitats using spatial predictions, and provides evidence of decadal stability in habitat use, supporting spatially explicit management measures as a suitable tool to protect dolphin key habitats. 
102

103

104

105

106

107

108

109

110

111

112

113

114

115

116

117

118

119

120

121

122

123

124

\section{MATERIAL AND METHODS}

\section{Study Area}

This study took place in the Chiloé archipelago in southern Chile $\left(41.8^{\circ}-43.4^{\circ} \mathrm{S}, 73.2^{\circ}-73.9^{\circ} \mathrm{W}\right)$ and comprised two survey areas (northern and southern, Figure 1) separated by about $70 \mathrm{~km}$ and covering a range of coastal habitats including islands, channels, bays and estuaries. This region is characterized by considerable freshwater input and variations in sea surface temperature (SST) and salinity (Dávila, Figueria, \& Müller, 2002; Iriarte, González, Liu, Rivas, \& Valenzuela, 2007; this study). The northern study area (near Castro) spanned roughly 260 km², with water depths up to $130 \mathrm{~m}$ and average depth of about $50 \mathrm{~m}$. The southern area (near Quellón) spanned roughly $275 \mathrm{~km}^{2}$, with water depths rarely exceeding $50 \mathrm{~m}$ and average depth of about $25 \mathrm{~m}$.

\section{Sampling Design and Data Collection}

Systematic boat-based habitat and sighting surveys for small cetaceans were carried out annually from January to April of 2002-2012, using $4.2 \mathrm{~m}$ inflatable boats with outboard engines. Surveys were conducted at $20 \mathrm{~km} / \mathrm{h}$ in favourable conditions, defined as Beaufort $\leq 3$, good visibility and little or no precipitation. Surveys were designed to ensure full coverage of the available habitat in the chosen study areas. Transects had variable start and end points and were placed in regularly spaced randomized zigzag patterns crossing bays and channels from shore to shore and extending up to $3,000 \mathrm{~m}$ offshore.

Two to four observers scanned the sea surface ahead and out to $90^{\circ}$ of the transect line for visual cues of dolphins. When dolphins were sighted, the observers recorded the position of the vessel on the transect line using Global Positioning System (GPS), the distance (estimated by eye in $\mathrm{m}$ ) and angle (estimated in degrees using a small angle board) to the 
125

126

127

128

129

130

131

132

sighting before approaching the dolphins to record more detailed information. This included species identification, group size, presence of offspring, dolphin behaviour and a suite of in situ environmental measurements (Table 1) made as close as possible to the original location where dolphins were first seen prior to approach (position also marked by GPS). This position constituted a presence point. Any further dolphin groups seen while working with the initial sighting were not included in the analyses presented here.

Environmental measurements (Table 1) included biologically relevant physiographic and oceanographic variables that served to characterize dolphin habitat (depth, distance to shore, distance to rivers, SST, water clarity, salinity) and anthropogenic variables (distances to nearest salmon and nearest shellfish farms). Distance variables were measured in situ using a Bushnell laser range finder for distances of $<1000 \mathrm{~m}$ (i.e. maximum range of equipment). Distances to coastline and rivers of $\geq 1000 \mathrm{~m}$ were derived in a GIS (Geographic Information System; Manifold System vers 8.0, using coordinate system WGS 1984 UTM Zone 18S and GSHHS high resolution coastline data). It was not possible to use GIS to calculate post-hoc distances to salmon and shellfish farms because the farms regularly changed location, extent and activity status. Mapping these frequent changes in situ was not feasible given the number of farms involved. However, the maximum distance between any given point in the study area and the nearest aquaculture farm was $7000 \mathrm{~m}$. Therefore, distances of $\geq 1000 \mathrm{~m}$ which could not be measured in situ (or when no farms were in visual range), were assigned random values from 1000 to $7000 \mathrm{~m}$ to facilitate the inclusion of distance to farms as continuous variables in the models. Thus, direct effects of aquaculture sites on dolphin distributions were only interpreted for distances within the measured range of $<1000 \mathrm{~m}$, and greater distances were considered uninformative for the modelled relationships. 
After all measurements had been taken during a sighting, survey effort resumed at the

initial point of departure from the transect line and continued along the original trajectory. If no dolphins were sighted while moving along the transects, the vessel was stopped at regular 15-min intervals to collect the same in situ environmental data as recorded during dolphin presence (Table 1). These 15-min stops for sampling without dolphins constituted the absence points of the analysis, and were considered true absences because sighting conditions and survey protocol would have allowed any dolphins present at that location to be detected. The randomized transect design and regular 15-min sampling at absence points along the transects ensured that the habitat types available to the dolphins in each study area were sampled representatively.

\section{Modelling}

All absence and presence points with their associated in situ measurements constituted the sample data for analyses. Dolphin probability of occurrence was modelled using binomial Generalized Additive Models (GAMs) (Hastie \& Tibshirani, 1990) with a logit link function. Analyses were carried out in software R 3.4.2 (R Core Team, 2017), using the mgcv library (Wood, 2006). Pairplots and variance inflation factors (Brauner \& Shacham, 1998) were used to inspect potential collinearity among covariates, but none was detected. The choice of variables (Table 1) was guided by their potential biological relevance as well as availability of reliable data measured at appropriate spatial and temporal resolutions, which ruled out using remotely sensed data (e.g. SST, chlorophyll concentration) or tidal predictions for the study areas. 
171 included as factor, see below), where the degree of smoothness was determined as part of 172 the model fitting process (Wood, 2006). Thin plate regression splines were used, because they 173 allow smoothing with respect to any number of covariates and do not require 'knot' locations 174 to be specified (Wood, 2006). GAMs have a tendency to over-fit (Wood, 2006), so the degrees 175 of freedom of each smooth was limited to 4.

Two types of models were fitted: the 'environmental (or explanatory) model' and the 'spatial model'. In the environmental model, all variables except latitude and longitude were included. Beaufort scale was included to take account of variation in detection probability as a function of sea conditions (Evans \& Hammond, 2004). Year was added as a factor, to explore differences among survey years. In the spatial model, additional spatial information (latitude and longitude) was included as an isotropic smooth (Wood, 2006), as a proxy for potentially spatially structured habitat characteristics that were not accounted for with the available environmental data. The best models were used to visualize the predictions of dolphin occurrence on the maps.

Two model selection methods were used. Shrinkage smoothers (Wood, 2006) were used on the full model (all candidate covariates) as an automated model selection. Shrinkage smoothers introduce an additional penalty that enables smooth terms to be penalized 188 ('shrunk' away) when the term makes no contribution to the model (Wood, 2006). Forward stepwise selection was used as a complementary method to assess the contribution of each covariate to the explained deviance, and to choose among models with or without factor variables. Here, each covariate was added to the null model (intercept only), one at a time.

192 The covariate that made the greatest model improvement was retained. All remaining 
194 continued until the inclusion of new covariates no longer improved the model, as judged by 195 the UBRE score and the approximate Akaike's Information Criterion (AIC) for GAMs (Wood, 196 2006). Covariates were retained if they reduced the AIC by at least 2 (Burnham \& Anderson, 197 2002).

198 The best models were used to visualize the predictions of dolphin occurrence in the 199 study areas. The 95\% confidence intervals (Cl) for predictions were calculated through non200 parametric bootstrap of the sample data, with replacement, using 500 replications and the 201 percentile method (Borchers, Buckland, \& Zucchini, 2002). The mean probability of occurrence 202 and the lower and upper $\mathrm{Cl}$ bounds were then plotted on maps to visualize the probability of occurrence as a measure of importance of different areas. All point-based predictions were exported into Manifold GIS and kriging was used to generate smooth colour-coded surfaces

for the habitat use maps. Information on the location and extent of registered aquaculture concessions for the year 2015, obtained from the Chilean Fisheries Service

207 (wwww.subpesca.cl), was then overlaid on the combined predicted habitat use surfaces for 208 both species to illustrate their recent spatial overlap in both study areas.

\section{RESULTS}

210 Field surveys covered a distance of $30,736 \mathrm{~km}$ during 489 days spread over 11 years. A total 211 of 531 Chilean dolphin sightings (32-80 annually) and 353 Peale's dolphin sightings (22-70 212 annually) were used for modelling, together with 2,461 absence points (178-408 annually, 213 Figure 1). Both species were encountered in all years and in both study areas, yet with 214 different encounter rates. Chilean dolphins were uncommon in the northern compared to the 215 southern study area ( 0.3 dolphin compared to 2 dolphins per $10 \mathrm{~km}$ surveyed), whereas 
216 Peale's dolphins were sighted more frequently in the northern than the southern study areas

217 (1 dolphin compared to 0.5 dolphin per $10 \mathrm{~km}$ surveyed).

218 Detection probabilities were not calculated because distance and angle estimates lacked 219 precision, were not available for all sightings and were affected by the low position of the 220 observers $(<2 \mathrm{~m})$. However, average radial distances of detection were almost identical for 221 both species (Chilean dolphins: $249 \mathrm{~m}, \mathrm{SD}=188 \mathrm{~m}$, Peale's dolphins: $256 \mathrm{~m}, \mathrm{SD}=204 \mathrm{~m}$ ), thus 222 differences in detection probability are unlikely to affect comparison of model results 223 between species. For both species, the different model selection methods resulted in the 224 same covariates retained in the final environmental and spatial models. Table 2 shows the 225 results of the forward stepwise selection for the environmental models, including the relative 226 contribution of covariates to the explained deviance.

\section{Chilean dolphins}

228 The final environmental model for Chilean dolphins retained all candidate covariates except 229 Year, and explained 33.2\% of the deviance (Table 2). The model fitted the data well (adjusted $230 \mathrm{R}^{2}$ for binary data $=0.43$ ). Fitted smooth functions are shown in Figure 2 . Distance to shore 231 was the most important predictor, explaining $17.8 \%$ of the deviance (Table 2). Probability of occurrence decreased with increasing distance to shore, and 95\% of all sightings of Chilean dolphins occurred within 500 m from shore. Depth was also an important predictor, with probability of occurrence decreasing with increasing depth, and $95 \%$ of all sightings were made in waters with depths shallower than $30 \mathrm{~m}$. Probability of occurrence decreased with increasing distance to shellfish farms, but increased with increasing distance to salmon farms. It was higher closer to rivers, in more turbid, somewhat less saline and relatively warmer waters. As expected, it decreased with increasing Beaufort scale. Year was not retained in the model, suggesting no significant inter-annual differences. 
The final spatial model included distance to shore, depth, SST, water clarity, distance to

241

242

243

244

245

246

247

248

249

250

251

252

253

254

255

256

257

258

259

260

261

262

263

nearest river, distance to nearest shellfish farm, distance to nearest salmon farm and Beaufort scale, plus the interaction of latitude and longitude, explained $42.1 \%$ of the deviance (adjusted $\mathrm{R}^{2}=0.52$ ), and was used to generate prediction maps. Visual comparison of prediction maps with the observed sightings indicated that the model correctly predicted areas of high occurrence probability where sightings were concentrated (Figures 1, 3 and 4).

Key areas for Chilean dolphins, based on high predicted probability of occurrence, were situated mostly in the southern study area: in Yaldad Bay, along the western shore of Isla Coldita, and in the channels around Isla San Pedro (Figure 3). These areas were predicted as important even when uncertainty (lower $95 \% \mathrm{Cl}$ bound) was taken into account (Figure 3c). Areas with few or no sightings were also correctly predicted as areas with low probability of occurrence, regardless of uncertainty. Mean model predictions appeared to under-predict occurrence at Isla Cailín; however, the upper $95 \% \mathrm{Cl}$ did predict this area to be important, while still predicting low probability of occurrence in adjacent waters (Figure 3b). The model predicted low overall probability of occurrence in the northern study area (Figure 4), with the exception of a few sheltered bays where the upper $95 \% \mathrm{Cl}$ indicated potentially higher probability of occurrence (Figure $4 b)$.

Peale's dolphin

The final environmental model for Peale's dolphins retained depth, distance to nearest shellfish farm, distance to shore, distance to nearest river, salinity, SST and Beaufort scale, explaining $16.1 \%$ of the deviance (Table 2 ) with an adjusted $R^{2}=0.21$. Fitted smooth functions are shown in Figure 5. Depth was the most important predictor, explaining $8.5 \%$ of the deviance. Probability of occurrence decreased with increasing water depth, and dolphins appeared to prefer waters shallower than $20 \mathrm{~m}$. The second most important predictor was 
distance to nearest shellfish farm, with probability of occurrence increasing with increasing distance from shellfish farms. Predictions suggested Peale's dolphins were more likely to be found within $400 \mathrm{~m}$ from shore, in SST $12.5-15^{\circ} \mathrm{C}$, further from river mouths, and in somewhat more saline waters.

The final spatial model retained fewer environmental variables than identified in the environmental model, and included depth, distance to shore, SST and distance to nearest river, plus the interaction of latitude and longitude. The model explained $32.3 \%$ of the deviance (adjusted $\mathrm{R}^{2}=0.40$ ), double the deviance explained by the environmental model, and was used to generate prediction maps. The mean predictions highlighted areas of highest occurrence in Canal Dalcahue and the channel of Castro in the northern study area (Figure 4), and off the southern shores of Islas Laitec and Cailín in the southern study area, but seemed to under-predict occurrence on the eastern side of Isla Coldita (Figure 3). As with Chilean dolphins, Year was not retained in any of the models for Peale's dolphins, indicating no significant inter-annual differences.

\section{Habitat predictions and aquaculture overlap}

Predictions of occurrence for both species were overlaid with officially registered concessions for salmon and shellfish farms in 2015 (Figure 6). Aquaculture concessions, in particular for shellfish farms, were widespread along the coasts and in sheltered bays of both study areas, and overlapped with or occurred close to predicted habitat, particularly for Chilean dolphins. Salmon farms were generally located a bit further away from predicted Chilean dolphin habitat, except for the channels around Isla San Pedro in the southern study area where farms occurred near or within core habitat of Chilean dolphins. Peale's dolphins showed less overlap with aquaculture sites than Chilean dolphins in the southern study area, 
288 but some of their predicted core habitat in the northern study area (particularly near 289 Dalcahue) abutted or overlapped with both salmon and shellfish concessions.

290

\section{DISCUSSION}

This study provides the first quantitative assessment of how sympatric Chilean and Peale's dolphins rely on different environmental characteristics of nearshore habitat, which appears to lead to fine-scale habitat partitioning in the Chiloé archipelago. Habitat use patterns for both species showed decadal stability with persistent key areas of occurrence. Aquaculture farming and associated activities were intense in both study areas and abutted or overlapped with areas identified as key dolphin habitats. Investigating habitat use patterns across fine spatial but large temporal scales using in situ data on environmental variables is a unique feature of this study, resulting in spatially explicit conservation and management implications for the species and region of study.

\section{Species-habitat relationships}

Habitat use patterns of Chilean dolphins in the Chiloé archipelago appeared to be strongly influenced by certain environmental conditions. Chilean dolphins occurred almost exclusively in waters shallower than $30 \mathrm{~m}$, and within $500 \mathrm{~m}$ from shore. Probability of occurrence was higher closer to river mouths and in bays with estuarine characteristics (e.g. lower water visibility, lower salinity). The presence of deep waters within channels and bays in the northern area might explain why Chilean dolphin occurrence was lower there compared to the southern area.

Shallow, nearshore waters influenced by rivers seem to be defining habitat characteristics for Chilean dolphins. These findings echo the few other habitat studies off the open coast north (Pérez-Álvarez, Alvarez, Aguayo-Lobo, \& Olavarría, 2007) and in channels 
311 south of Chiloé (Viddi, Harcourt, \& Hucke-Gaete, 2015), as well as most of the incidental

312 sighting locations reported for this species (Aguayo-Lobo et al., 1998; Capella, Gibbons, \& 313 Vilina, 1999; Goodall et al., 1988; Morgenthaler, Fernández, Moraga, \& Olavarría, 2014; 314 Zamorano-Abramson et al., 2010). The four dolphins of the genus Cephalorhynchus, to which 315 the Chilean dolphin belongs, are all characterized as coastal shallow-water species (Dawson, 316 2018), with Commerson's dolphins (C. commersonnii) and Hector's dolphins (C. hectori, Van 317 Beneden 1881) also commonly sighted in turbid waters or near river mouths (Bräger et al., 318 2003; Goodall, 1994).

River mouths and estuaries are known areas of enhanced productivity, often aggregating fish and serving as fish nurseries, in turn attracting piscivorous predators such as dolphins (Arso Civil et al., 2019; Parra, Schick \& Corkeron, 2006). Intense seasonal phytoplankton blooms occur in the inshore waters off Chiloé (Iriarte et al., 2007) and in estuaries such as Yaldad Bay (Navarro \& Jaramillo, 1994) identified as key Chilean dolphin habitat in this study. Systematic information on Chilean dolphin diet is lacking, but field observations (this study, Viddi et al., 2015) suggest that they might feed on schooling sardines (Strangomera spp.), Patagonian blenny (Eleginops maclovinus, Cuvier 1830) and silversides (Odontesthes spp.), which are known to spawn in and inhabit estuaries as juveniles (Dyer, 2000). Chilean dolphins at Chiloé spent a large proportion of their time foraging (Heinrich, 2006; Ribeiro et al., 2007), which is typical for small bodied cetaceans with high energetic demands requiring high rates of energy intake (Wisniewska et al., 2016). Thus, Chilean dolphin habitat use appeared to be driven by environmental features that may serve to aggregate and maintain sufficiently abundant and reliable prey resources. Mark-recapture studies of

333 identifiable individuals at southern Chiloé indicate that the local population of Chilean dolphins is small ( 60 adults) with individuals showing high site fidelity and limited along- 
335 shore movements (Heinrich, 2006). The availability of suitable habitat and resulting effects on

336

337

338

339

340

341

342

343

344

345

346

347

348

349

350

351

352

353

354

355

356

357

358

dolphin carrying capacity could be important factors in determining overall distribution, abundance and population structure.

Genetic studies have shown clear population differences between Chilean dolphins along the open coast north of Chiloé and to the south in the deep fjords (Pérez-Alvarez et al., 2015). Similar, and even more fine-scale, genetic differences and strong population structuring have also been found in congeneric Commerson's dolphins (Cipriano, Hevia, \& Iñíguez, 2011) and Hector's dolphins (Hamner, Pichler, Heimeier, Constantine, \& Baker, 2012; Pichler, Dawson, Slooten, \& Baker, 1998), and might be a feature of Cephalorhynchus dolphins, generally. Unfortunately, Chilean dolphins in the intermediate Chiloé region have not been sampled (Pérez-Álvarez et al., 2015), so finer-scale population structure remains unknown, but obtaining such information should be a priority given the distinct and stable habitat use patterns described here.

Sheltered, shallow nearshore waters might also confer a lower risk of predation. Killer whales are rarely seen in the Chiloé archipelago and have not been observed in Chilean dolphin habitat, but they are known to predate marine mammals in the Chilean fjords (Häussermann, Acevedo, Försterra, Bailey, \& Aguayo-Lobo, 2013). Fear and predator avoidance are powerful sub-lethal forces that shape behaviour and habitat use patterns of prey even when predation events appear rare (Wirsing, Heithjaus, Frid, \& Dill, 2008).

Depth, distance to shore and distance to rivers were also important predictor variables for the occurrence of Peale's dolphins. They also used shallow waters $(<20 \mathrm{~m})$ close to shore $(<400 \mathrm{~m})$ but also occurred further offshore $(>1,000 \mathrm{~m})$ over shallow sandbanks and shoals. In contrast to Chilean dolphins, Peale's dolphins were found further from rivers, and along more open or exposed shorelines and along the shores of wider and deeper channels in the northern 
359 study area. The diet of Peale's dolphins in the Chiloé archipelago is not known, but they were 360 never observed feeding on small schooling fish as Chilean dolphins were (S. Heinrich, pers. obs.). In other parts of their range, Peale's dolphins seem to have a generalist diet based on demersal and shallow water prey (e.g. fish, octopus, shrimp; Iñíguez \& de Haro, 1994; Schiavini et al., 1997). Therefore, Peale's dolphin habitat use might reflect different foraging strategies 364 involving transit between more patchily distributed or less productive prey patches, and is 365 likely also influenced by other ecological needs. The only other distribution modelling studies 366 of Peale's dolphins, both on spatial scales an order of magnitude greater than this study, 367 seemed to support broader habitat use patterns. Peale's dolphins in the Chilean fjords and 368 southern Argentina were seen 10 s of $\mathrm{km}$ from shore but always in the neritic zone (usually in $369<100 \mathrm{~m}$ water depth) (Dellabianca et al., 2016; Viddi et al., 2010). Compared to Chilean 370 dolphins, greater ecological plasticity in Peale's dolphins is to be expected given their much

371 wider distributional range spanning both southern South Pacific and South Atlantic 372 continental shelf waters (Cipriano, 2018). Identifying key habitat and habitat partitioning

For both species, including spatial components improved the predictive ability of the 376 models, but particularly so for Peale's dolphins. While spatial covariates do not elucidate 377 ecological relationships, they helped to improve predictions by capturing spatially linked 378 differences in habitat characteristics that were or could not be measured. The predictive 379 habitat use maps closely matched the distribution of the actual sighting locations. Core areas 380 for Chilean dolphins remained consistent even when model uncertainty was mapped as lower 381 and upper $95 \%$ confidence intervals (Cls). Spatial occurrence patterns of Peale's dolphins were 
382

383

more ambiguous across lower and upper $\mathrm{Cls}$, reflecting greater variability in the sighting data and less strong relationships with the available environmental covariates.

There was very little fine-scale spatial overlap between the two species, particularly in southern Chiloé, where Peale's dolphins were never seen in core Chilean dolphin habitat. Short-term associations or direct interactions between the two species were rarely observed, even where their selected habitats seemed to overlap (Heinrich et al., 2010). This differs markedly from the regular co-occurrence and frequent, at least short-term mixed group associations reported for Peale's dolphins and Commerson's dolphins in Argentina (de Haro \& Iñíguez, 1997; Goodall et al., 1997).

Sympatric co-existence of similar species is shaped by resource availability (e.g. abundance of prey), predation pressure and habitat complexity. Within their physiological and ecological constraints, different strategies enable sympatric species to co-exist, including spatial or temporal differences in habitat use, dietary divergence and specialization, as well as differences in activity patterns and socially mediated behaviours (Bearzi, 2005; Parra, 2006). In some sympatric cetaceans, aggressive interactions act to maintain patterns of fine-scale habitat partitioning, with usually the smaller species avoiding the larger, more dominant one (Parra, 2006; Thompson, White, \& Dickson, 2004). Aggressive interactions between Chilean and Peale's dolphins have not been documented, and the observed fine-scale habitat partitioning at Chiloé likely reflects the more specialist habitat preferences of Chilean dolphins, and the greater ecological plasticity of Peale's dolphins enabling them to exploit a wider range of habitats and resources. 
405 Aquaculture activities were intense and wide-spread throughout the study areas. For 406 both species, distances to farm sites were retained as predictor variables in the environmental 407 habitat models. There was a strong positive relationship between Chilean dolphin occurrence 408 and proximity to shellfish farms, but the opposite pattern for salmon farms. In contrast, 409 Peale's dolphin occurrence increased with increasing distance to shellfish farms, with no 410 apparent relationship with distance to salmon farms. These relationships should not be 411 interpreted as Chilean dolphins being attracted to shellfish farms, or Peale's and Chilean 412 dolphins actively avoiding shellfish and salmon farms, respectively. A more plausible 413 explanation is that the location of the two types of aquaculture overlapped more or less with 414 the dolphins' preferred habitat, and thus acted as a proxy for a set of habitat characteristics.

415 Shellfish, in particular mussels (Mytilidae), are cultivated on vertical lines suspended 416 from horizontal surface longlines buoyed by floats. These farms require a minimum water 417 depth of around 8-10 m and high primary productivity and nutrient flow, conditions often 418 encountered in or near estuaries (e.g. Yaldad Bay). These characteristics match those selected 419 by Chilean dolphins, but not so much those of Peale's dolphins. Where shellfish farms and 420 Chilean dolphins co-occurred, the dolphins were observed to move in the corridors between 421 the shore and the outer shoreward longlines of the farms (Heinrich \& Fuentes, pers. obs.). 422 Although they occasionally were observed inside the perimeter of shellfish farms, Chilean 423 dolphins appeared to avoid areas with more than 30\% coverage of surface longlines in Yaldad 424 Bay (Ribeiro et al., 2007). Thus, large shellfish farms might reduce the availability of habitat 425 important to Chilean dolphins. Similar exclusion effects and potentially lost foraging 426 opportunities have been reported for shellfish farms and dusky dolphins (L. obscurus, Gray 427 1828) in New Zealand (Markowitz et al., 2004; Pearson et al., 2012) and Indo-Pacific 428 bottlenose dolphins (Tursiops aduncus, Ehrenberg 1833 ) in Australia (Watson-Capps \& Mann, 
429 2005). In contrast, shellfish farms in Spain that used floating rafts instead of longlines were 430 found to attract common bottlenose dolphins (T. truncatus, Montagu 1821); these structures 431 might provide predictable and enhanced foraging opportunities for the dolphins by attracting 432 and harbouring wild fish (Díaz López \& Methion, 2017). A recent review found that the 433 responses of mobile organisms associated with farming structures differed substantially in 434 nature (from attraction to repulsion) and across spatial and temporal scales (Callier et al., 435 2017). Thus, scale and species-specific responses should be carefully considered in studies and 436 management of aquaculture effects on wild fauna.

Predicted occurrence of Chilean dolphins increased with distance to salmon farms (within $1000 \mathrm{~m}$ ), but neither Chilean nor Peale's dolphin habitat selection seemed to be directly influenced by the distribution of salmon farms. These farms were more abundant in 440 the northern study area and tended to be located in deeper waters ( $>20 \mathrm{~m}$ ) which limited their spatial proximity to preferred Chilean dolphin habitat. Acoustic harassment devices aimed at 442 deterring predatory attacks of pinnipeds on caged farm fish can induce area avoidance in small 443 cetaceans (Olesiuk, Nichol, Sowden, \& Ford, 2002), but such devices were not used by fish 444 farms in the Chiloé archipelago during the study period (Sepúlveda \& Oliva, 2005; Heinrich, 445 pers. obs.).

$446 \quad$ Even though the modelling results show limited direct spatial overlap between dolphins 447 and salmon farms, the expansion and intensification of fish farming in the coastal marine 448 environment might still affect both species through cascading ecosystem effects. The Chilean 449 salmon farming industry has faced substantial criticism for their inadequate handling of 450 disease outbreaks, misuse of antibiotics, and regular accidental (and intentional) releases of 451 millions of farmed salmon into the coastal waters off Chiloé, all of which threaten the health 452 and function of the coastal marine ecosystem (Asche, Hansen, Tveteras, \& Tveterås, 2009; 
453 Buschmann et al., 2012; Gomez-Uchida et al., 2018; Niklitschek, Soto, Lafon, Molinet, \& 454 Toledo, 2013; Sepúlveda et al., 2013). Managing and adapting aquaculture practices to reduce 455 negative effects might be a more promising mitigation strategy than excluding anthropogenic 456 activities outright. If this approach was adopted, monitoring and enforcement of appropriate 457 aquaculture practices in general, and close to key dolphin habitat in particular, should be a 458 priority. Supporting measures that should be put in place include a requirement for proper 459 maintenance of existing aquaculture farms and removal of structures no longer in use (e.g. 460 shellfish long-lines and floats) to reduce potential habitat exclusion effects, particularly for 461 Chilean dolphins. Under the precautionary principle restrictions on new farming concessions 462 should be introduced until better information about the risks and magnitude of impacts of the 463 farming activities on the coastal marine ecosystem and its dependent species is obtained 464 (Niklitschek et al., 2013).

The identified differences in the responses of the two dolphin species to aquaculture 466 farms also highlights important methodological considerations. Species distribution models 467 should include anthropogenic variables in areas of intense human activities, as the latter might 468 be interacting with or even altering the natural habitat use patterns of the species of interest. 469 Species interactions with aquaculture should be investigated on a species- and context470 specific basis.

\section{Conservation implications}

A distinguishing feature of this study was the use of long-term (11 years), 474 systematically in situ collected data to investigate fine-scale habitat use patterns of two 475 sympatric cetacean species in a coastal environment under pressure from human activities. 476 The observed species-environment relationships and resulting habitat use patterns for both 
477 species remained stable over a decade. Such long-term stability in habitat use is important 478 when considering spatially explicit conservation measures, such as marine protected areas 479 (Hartel, Constantine \& Torres, 2015; Wilson, Reid, Grellier, Thompson, \& Hammond, 2004). 480 The channels around Isla San Pedro, Coldita and Yaldad Bay in southern Chiloé constitute key 481 habitat for a small, resident population of Chilean dolphins (this study; Heinrich, 2006), and 482 should be considered as the first priority conservation area for Chile's only endemic cetacean 483 in regional marine spatial planning and coastal zoning.

Our study was limited to austral summers and autumns. Winter field activities in southern Chile are hampered by challenging logistics, poor light and inclement weather conditions (Darwin, 1860). Observations from short sighting surveys during winter (2004, 487 2010) and year-round static passive acoustic monitoring (PAM) (2013-14) indicated that Chilean dolphins continued to use the same key areas in Yaldad Bay and around Isla San Pedro throughout the year (Heinrich, unpublished data). Static PAM appears to be a particularly useful tool to monitor patterns of seasonal habitat use in the identified core habitat or dolphin occurrence around aquaculture farms given the method's independence of weather and light conditions (Mellinger, Stafford, Moore, Dziak, \& Matsumoto, 2007).

Although our study identified several high-occurrence areas for Peale's dolphins (e.g. Canal Dalcahue, shoals south of Islas Laitec and Cailín), fine-scale spatial conservation measures might be less suitable due to this species' wider ranging habits. While their more generalist nature might make Peale's dolphins less susceptible to localized habitat impacts, it might also expose them to a wider range of anthropogenic pressures regionally. Therefore, Peale's dolphins and other highly mobile marine predators would likely benefit most from an 499 integrated, region-wide ecosystem approach to managing ongoing and intensifying 
500 anthropogenic activities, such as the continued expansion of aquaculture into more remote 501 and less impacted southern fjords (Fernández \& Castilla, 2005).

502 The identified important habitats for Chilean and Peale's dolphins are highly relevant 503 for coastal and marine spatial planning in the Chiloé archipelago. The results also have 504 implications beyond the boundaries of our study areas. The established species-environment 505 relationships could be used to predict potentially important habitats for each species in the 506 southern fjords. This region is the focus for major planned expansions of the Chilean salmon 507 farming industry (Niklitschek et al., 2013), yet conducting systematic marine surveys in this 508 vast fjordic region is logistically challenging and prohibitively expensive. Range-wide 509 abundance estimates are lacking for both species, but have been deemed a conservation 510 priority for Chilean dolphins given concerns about the species' past exploitation, suspected 511 low abundance, and potentially declining populations (Heinrich \& Reeves, 2017). While 512 extrapolated habitat predictions should be treated with caution, they could serve to identify 513 potentially important areas where dedicated studies of dolphin abundance should be 514 conducted or where dolphin habitat use and anthropogenic activities are most likely to 515 overlap (Elith \& Leathwick, 2009; Mannocci, Roberts, Miller, \& Halpin, 2017). Spatial 516 predictions of important dolphin habitat could also be included in region-wide marine spatial 517 planning and conservation zoning initiatives (Guisan et al., 2013; Vila et al., 2016).

\section{ACKNOWLEDGEMENTS}

519 The authors declare that they have no conflict of interest. Field work and navigation were 520 authorized by the Subsecretaría de Pesca (SubPesca), the Servicio Hidrografico y 521 Oceanografico de la Armada (SHOA), and the Armada de Chile. The long-term project received 522 core funding from the Organization for the Conservation of South American Aquatic Mammals 
523

524

525

526

527

528

529

530

531

- YAQU PACHA e.V., The Zoological Garden Nürnberg (Germany), the European Association for

Aquatic Mammals (EAAM) and the World Association of Zoos and Aquariums (WAZA). Logistic

support and equipment loans were provided by the University of St Andrews (UK) and the

Universidad Austral de Chile. T.G. was supported by a Master of Research scholarship from

the Slovene Human Resources Development and Scholarship Fund. We thank all the field assistants for their help with data collection, Clint Blight for providing invaluable help with GIS, Mike Lonergan for offering statistical advice, and René Swift for constructive discussions. We extend thanks to the reviewers for their constructive comments that improved the original manuscript.

\section{REFERENCES}

Aguayo-Lobo, A., Torres Navarro, D., \& Acevedo Ramírez, J. (1998). Los mamíferos marinos de Chile: I. Cetacea. Serie Cientifica Instituto Antártico Chileno, 48, 19-159.

Arso Civil, M., Quick, N.J., Cheney, B., Pirotta, E., Thompson, D. and Hammond, P.S. (2019). Changing distribution of the east coast of Scotland bottlenose dolphin population and the challenges of areabased management. Aquatic Conservation: Marine and Freshwater Ecosystems.PLEASE INSERT DETAILS THIS PAPER IS PART OF SAME SAUPPLEMEWNT

Asche, F., Hansen, H., Tveteras, R., \& Tveterås S. (2009). The salmon disease crisis in Chile. Marine Resource Economics, 24, 405-411.

Ashe, E., Noren, D.P., \& Williams, R. (2010). Animal behaviour and marine protected areas: incorporating behavioural data into the selection of marine protected areas for an endangered killer whale population. Animal Conservation, 13, 196-203.

Bailey, H., \& Thompson, P.M. (2009). Using marine mammal habitat modelling to identify priority conservation zones within a marine protected area. Marine Ecology Progress Series, 378, 279-287.

Bearzi, M. (2005). Dolphin sympatric ecology. Marine Biology Research, 1, 165-175.

Bonizzoni, S., Furey, N.B., Pirotta, E., Valavanis, V.D., Würsig, B.,\& Bearzi, G. (2014). Fish farming and its appeal to common bottlenose dolphins: modelling habitat use in a Mediterranean embayment. Aquatic Conservation: Marine and Freshwater Ecosystems, 24, 696-711.

Borchers, D.L., Buckland, S.T., \& Zucchini, W. (2002). Estimating Animal Abundance: Closed Populations. London, UK: Springer.

Bostock, J., McAndrew, B., Richards, R., Jauncey, K., Telfer, T., Lorenzen, K.,... Corner, R. (2010). Aquaculture: global status and trends. Philosophical Transactions of the Royal Society of London. Series B, Biological Sciences, 365, 2897-2912.

Bräger, S., Harraway, J.A., \& Manly, B.F.J. (2003). Habitat selection in a coastal dolphin species (Cephalorhynchus hectori). Marine Biology, 143, 233-244.

Brauner, N., \& Shacham, M. (1998). Role of range and precision of the independent variable in regression of data. AIChE Journal, 44, 603-611.

Burnham, K.P., \& Anderson, D.R. (2002). Model Selection and Multimodel Inference: A Practical Information-Theoretic Approach ( $2^{\text {nd }}$ ed.). New York, USA: Springer. 
Buschmann, A.H., Cabello, F., Young, K., Carvajal, J., Varela, D.A., \& Henríquez L. (2009). Salmon aquaculture and coastal ecosystem health in Chile: Analysis of regulations, environmental impacts and bioremediation systems. Ocean \& Coastal Management, 52, 243-249.

Buschmann, A.H., López, D.A., \& Medina, A. (1996). A review of the environmental effects and alternative production strategies of marine aquaculture in Chile. Aquacultural Engineering, 15, 397421.

Buschmann, A.H., Tomova, A., López, A., Maldonado, M.A., Henríquez, L.A., Ivanova, L., ... Cabello, F.C. (2012). Salmon aquaculture and antimicrobial resistance in the marine environment. PLoS ONE, 7, e42724. DOI: 10.1371/journal.pone.0042724.

Callier, M.D., Byron, C.J., Bengtson, D.A., Cranford, P.J., Cross, S.F., Focken, U., ... McKindsey, C.W. (2017). Attraction and repulsion of mobile wild organisms to finfish and shellfish aquaculture: a review. Reviews in Aquaculture, doi: 10.1111/raq.12208.

Cañadas, A., Sagarminaga, R., De Stephanis, R., Urquiola, E., \& Hammond, P.S. (2005). Habitat preference modelling as a conservation tool: proposals for marine protected areas for cetaceans in southern Spanish waters. Aquatic Conservation: Marine and Freshwater Ecosystems, 15, 5, 495521.

Capella, J., Gibbons, J.E., \& Vilina, Y. (1999). Nuevos registros del delfín chileno, Cephalorhynchus eutropia (Gray, 1846) en Chile central, extremo norte de su distribución. Estudios Oceanológicos, 18, 65-67.

Cipriano, F. (2018). Peale's dolphin Lagenorhynchus australis. Würsig, B., Thewissen, J.G.M., \& Kovacs, K. (Eds.) Encyclopedia of Marine Mammals (3rd ed.) (pp 698-701), San Diego, USA: Academic Press.

Cipriano, F., Hevia, M., \& Iñíguez, M. (2011). Genetic divergence over small geographic scales and conservation implications for Commerson's dolphins (Cephalorhynchus commersonii) in southern Argentina. Marine Mammal Science, 27, 701-718.

Darwin, C.R. (1860). A naturalist's voyage round the world: The voyage of the Beagle. (11 $\left.{ }^{\text {th }} \mathrm{ed}\right)$, eBooks@Adelaide, University of Adelaide, Australia.

Dávila, P.M., Figueria, D., \& Müller, E. (2002). Freshwater input into the coastal ocean and its relation with the salinity distribution off austral Chile (35-55S). Continental Shelf Research, 22, 521-534.

Dawson, S.M. (2018). Cephalorhynchus Dolphins. Würsig, B., Thewissen, J.G.M., \& Kovacs K. (Eds.) Encyclopedia of Marine Mammals (3rd ed.) (pp 166-172), San Diego, USA: Academic Press.

de Haro, J.C., \& Iñíguez, M.A. (1997). Ecology and behaviour of the Peale's dolphin, Lagenorhynchus australis (Peale, 1848) at Carbo Virgenes in Patagonia, Argentina. Report of the International Whaling Commission, 47, 723-727.

Dellabianca, N.A., Pierce, G.J., Rey, A.R., Scioscia, G., Miller, D.L., Torres, M.A., ... Schiavini, A.C. (2016). Spatial models of abundance and habitat preferences of Commerson's and Peale's dolphin in southern Patagonian waters. PLOS ONE, 11, e0163441. DOI: 10.1371/journal.pone.0163441.

Díaz López, B., \& Methion, S. (2017). The impact of shellfish farming on common bottlenose dolphins' use of habitat. Marine Biology, 164, 83.

Díaz López, B., \& Bernal Shirai, J.A.B. (2007). Bottlenose dolphin (Tursiops truncatus) presence and incidental capture in a marine fish farm on the north-eastern coast of Sardinia (Italy). Journal of the Marine Biological Association of the UK, 87, 113-117.

Dyer, B.S. (2000). Systematic review and biogeography of the freshwater fishes of Chile. Estudios Oceanológicos, 19, 77-98.

Elith, J., \& Leathwick, J.R. (2009). Species distribution models: ecological explanation and prediction across space and time. Annual Review of Ecology, Evolution, and Systematics, 40, 677-697.

Esteban, R., Verborgh, P., Gauffier, P., Giménez, J., Afán, I., Cañadas, A., ... de Stephanis, R. (2014). Identifying key habitat and seasonal patterns of a critically endangered population of killer whales. Journal of the Marine Biological Association of the United Kingdom, 94, 1317-1325.

Evans, P.G.H., \& Hammond, P.S. (2004). Monitoring cetaceans in European waters. Mammal Review, 34, 131-156.

Fernández, M., \& Castilla, J.C. (2005). Marine conservation in Chile: historical perspective, lessons, and challenges. Conservation Biology, 19, 1752-1762. 
613

614

615

616

617

618

619

620

621

622

623

624

625

626

627

628

629

630

631

632

633

634

635

636

637

638

639

640

641

642

643

644

645

646

647

648

649

650

651

652

653

654

655

656

657

658

659

660

661

662

663
Goodall, R.N.P. (1994). Commerson's dolphin Cephalorhynchus commersonii (Lacepede 1804). Ridgway, S.H., \& Harrison, R. (Eds.) Handbook of Marine Mammals. Volume 5: The First Book of Dolphins (pp 241-268). London, UK: Academic Press.

Goodall, R.N.P., Norris, K.S., Galeazzi, A., Oporto, J., \& Cameron, I.S. (1988). On the Chilean dolphin, Cephalorhynchus eutropia (Gray, 1846). Report of the International Whaling Commission Special Issue, 9, 197-257.

Goodall, R.N.P., Norris, K.S., Schevill, W.E., Fraga, F., Praderi, R., Iñíguez, M.A., \& de Haro, C. (1997). Review and update on the biology of the Peale's dolphin, Lagenorhynchus australis. Reports of the International Whaling Commission, 47, 777-796.

Gomez-Uchida, D., Sepúlveda, M., Ernst, B., Contador, T. A., Neira, S., \& Harrod, C. (2018). Chile's salmon escape demands action. Science, 361, 857-858.

Götz, T., Antunes, R., \& Heinrich, S. (2010). Echolocation clicks of free-ranging Chilean dolphins (Cephalorhynchus eutropia). Journal of the Acoustical Society of America, 128, 563-566.

Gregr, E.J., Baumgartner, M.F., Laidre, K.L., \& Palacios, D.M. (2013). Marine mammal habitat models come of age: the emergence of ecological and management relevance. Endangered Species Research, 22, 205-212.

Guisan, A., Tingley, R., Baumgartner, J.B., Naujokaitis-Lewis I., Sutcliffe P.R., Tulloch A.I.T., ...Buckley, Y.M. (2013). Predicting species distributions for conservation decisions. Ecology Letters, 16, 14241435.

Guisan, A., \& Zimmermann, N.E. (2000). Predictive habitat distribution models in ecology. Ecological Modelling, 135, 147 - 186.

Hamner, R.M., Pichler, F.B., Heimeier, D., Constantine, R., \& Baker, C.S. (2012). Genetic differentiation and limited gene flow among fragmented populations of New Zealand endemic Hector's and Maui's dolphins. Conservation Genetics, 13, 987-1002.

Hartel, E.F., Constantine, R., \& Torres, L.G. (2015). Changes in habitat use patterns by bottlenose dolphins over a 10-year period render static management boundaries ineffective. Aquatic Conservation: Marine and Freshwater Ecosystems, 25, 701-711.

Hastie, T.J., \& Tibshirani, R.J. (1990). Generalized Additive Models: Chapman \& Hall.

Häussermann, V., Acevedo, J., Försterra, G., Bailey, M., \& Aguayo-Lobo, A. (2013). Killer whales in Chilean Patagonia: additional sightings, behavioural observations, and individual identifications. Revista de Biologia Marina y Oceanografia, 48, 73-85.

Heinrich, S. (2006). Ecology of Chilean dolphins and Peale's dolphins at Isla Chiloé, southern Chile (PhD thesis). University of St Andrews, UK.

Heinrich, S., Elwen, S., \& Bräger, S. (2010). Patterns of Sympatry in Lagenorhynchus and Cephalorhynchus: Dolphins in Different Habitats. Würsig, B. \& Würsig, M. (Eds.) The Dusky Dolphin: Master Acrobat off Different Shores (pp 313-332), London, UK: Academic Press..

Heinrich, S., \& Reeves, R.R. (2017). Cephalorhynchus eutropia. The IUCN Red List of Threatened Species 2017. http://dx.doi.org/10.2305/IUCN.UK.2017-3.RLTS.T4160A50351955.en. Downloaded on 30 June 2018.

IUCN-MMPATF. (2016). Initial guidance on the use of selection criteria for the identification of Important Marine Mammal Areas (IMMAs), Version: October 2016, 60 pp.

Ingram, S.N., Walshe, L., Johnston, D., \& Rogan E. (2007). Habitat partitioning and the influence of benthic topography and oceanography on the distribution of fin and minke whales in the Bay of Fundy, Canada. Journal of the Marine Biological Association of the United Kingdom, 87, 149-156.

Iñiguez, M.A., \& de Haro, J.C. (1994). Preliminary reports of feeding habits of the Peale's dolphins (Lagenorhynchus australis) in southern Patagonia. Aquatic Mammals, 2, 35-37.

Iriarte, J.L., González, H.E., Liu, K.K., Rivas, C., \& Valenzuela, C. (2007). Spatial and temporal variability of chlorophyll and primary productivity in surface waters of southern Chile $\left(41.5-43^{\circ} \mathrm{S}\right)$. Estuarine, Coastal and Shelf Science, 74, 471-480.

Lecours, V. (2017). On the Use of Maps and Models in Conservation and Resource Management (Warning: Results May Vary). Frontiers in Marine Science, 4. doi:10.3389/fmars.2017.00288. 
Kemper, C.M., \& Gibbs, S.E. (2001). Cetacean interactions with tuna feedlots at Port Lincoln, South Australia and recommendations for minimizing entanglements. Journal of Cetacean Research and Management, 3, 283-292.

Kemper, C.M., Pemberton, D., Cawthorn, M., Heinrich, S., Mann, J., Würsig, B., ... Gales, R. (2003). Aquaculture and marine mammals: Co-existence or conflict? In Gales N., Hindell M. and Kirkwood R. (eds) Marine Mammals: Fisheries, Tourism and Management Issues (pp 208-225), Melbourne, Australia: CSIRO publishing.

Kyhn, L.A., Jensen, F.H., Beedholm, K., Tougaard, J., Hansen, M., \& Madsen, P.T. (2010). Echolocation in sympatric Peale's dolphins (Lagenorhynchus australis) and Commerson's dolphins (Cephalorhynchus commersonii) producing narrow-band high-frequency clicks. Journal of Experimental Biology, 213, 1940-1949.

Lecours, V. (2017) On the Use of Maps and Models in Conservation and Resource Management (Warning: Results May Vary). Frontiers in Marine Science, 4. Doi: 10.3389/fmars.2017.00288.

Mannocci, L., Laran, S., Monestiez, P., Doremus, G., Van Canneyt, O., Watremez, P., \& Ridoux V. (2014). Predicting top predator habitats in the south west Indian Ocean. Ecography, 37, 261-278.

Mannocci, L., Roberts, J.J., Miller, D.L., \& Halpin, P.N. (2017). Extrapolating cetacean densities to quantitatively assess human impacts on populations in the high seas. Conservation Biology, 31, 601614.

Markowitz, T.M., Harlin, A.D., Würsig, B., \& McFadden, C.J. (2004). Dusky dolphin foraging habitat: overlap with aquaculture in New Zealand. Aquatic Conservation: Marine and Freshwater Ecosystems, 14, 133-149.

Mellinger, D.K., Stafford, K.M., Moore, S., Dziak, R.P., \& Matsumoto, H. (2007). Fixed passive acoustic observation methods for cetaceans. Oceanography, 20, 36-45.

Morgenthaler, A., Fernández, J., Moraga, R., \& Olavarría, C. (2014). Chilean dolphins on the Argentine Atlantic coast. Marine Mammal Science, 30, 782-787.

Morisaka, T., \& Connor, R. (2007). Predation by killer whales (Orcinus orca) and the evolution of whistle loss and narrow-band high frequency clicks in odontocetes. Journal of Evolutionary Biology, 20, 1439-1458.

Navarro, J.M., \& Jaramillo, R. (1994). Evaluacion de la oferta alimentaria natural disponible a organismos filtradores de la Bahia de Yaldad $\left(43^{\circ} 08,73^{\circ} 44^{\prime}\right)$, sur de Chile. Revista de Biologia Marine, 29, 57-75.

Niklitschek, E.J., Soto, D., Lafon, A., Molinet, C., \& Toledo, P. (2013). Southward expansion of the Chilean salmon industry in the Patagonian Fjords: main environmental challenges. Reviews in Aquaculture, 5, 172-195.

Olesiuk, P. F., Nichol, L. M., Sowden, M. J., \& Ford, J. K. B. (2002). Effect of the sound generated by an acoustic harassment device on the relative abundance and distribution of harbor porpoises (Phocoena phocoena) in Retreat Passage, British Columbia. Marine Mammal Science, 18, 843-862.

Parra, G.J. (2006). Resource partitioning in sympatric delphinids: space use and habitat preferences of Australian snubfin and Indo-Pacific humpback dolphins. Journal of Animal Ecology, 75, 862-874.

Parra, G.J., Schick, R., \& Corkeron, P.J. (2006). Spatial distribution and environmental correlates of Australian snubfin and Indo-Pacific humpback dolphins. Ecography, 29, 396-406.

Pearson, H., Vaughn-Hirshorn, R., Srinivasan, M., \& Würsig B. (2012). Avoidance of mussel farms by dusky dolphins (Lagenorhynchus obscurus) in New Zealand. New Zealand Journal of Marine and Freshwater Research, 46, 567-574.

Pérez-Alvarez, M.J., Alvarez, E., Aguayo-Lobo, A., \& Olavarría, C. (2007). Occurrence and distribution of Chilean dolphin (Cephalorhynchus eutropia) in coastal waters of central Chile. New Zealand Journal of Marine and Freshwater Research, 41, 405-409.

Pérez-Alvarez, M. J., Olavarría, C., Moraga, R., Baker, C. S., Hamner, R. M., \& Poulin, E. (2015). Microsatellite Markers Reveal Strong Genetic Structure in the Endemic Chilean Dolphin. PLoS ONE, 10, e0123956. doi:10.1371/journal.pone.0123956. 
Pérez-Jorge, S., Pereira, T., Corne, C., Wijtten, Z., Omar, M., Katello, J., ... Louzao, M. (2015). Can Static Habitat Protection Encompass Critical Areas for Highly Mobile Marine Top Predators? Insights from Coastal East Africa. PLOS ONE, 10, e0133265.

Pichler, F., Dawson, S., Slooten, E., \& Baker, C. (1998). Geographic isolation of Hector's dolphin populations described by mitochondrial DNA sequences. Conservation Biology, 12, 676-682.

Piroddi, C., Bearzi, G., \& Christensen, V. (2011). Marine open cage aquaculture in the eastern Mediterranean Sea: a new trophic resource for bottlenose dolphins. Marine Ecology Progress Series, 440, 255-266.

R Core Team. (2017). R: A language and environment for statistical computing. R Foundation for Statistical Computing, Vienna, Austria. www.R-project.org/.

Redfern, J. V., Ferguson, M. C., Becker, E. A., Hyrenbach, K. D., Good, C., Barlow, J., ...Werner, F. (2006). Techniques for cetacean-habitat modelling. Marine Ecology Progress Series, 310, 271-295.

Redfern, J. V., McKenna, M. F., Moore, T. J., Calambokidis, J., Deangelis, M. L., Becker, E. A., ... Chivers, S. J. (2013). Assessing the Risk of Ships Striking Large Whales in Marine Spatial Planning. Conservation Biology, 27, 292-302.

Ribeiro, S., Viddi, F.A., Cordeiro, J.L., \& Freitas, T.R.O. (2007). Fine-scale habitat selection of Chilean dolphins (Cephalorhynchus eutropia): interactions with aquaculture activities in southern Chiloé Island, Chile. Journal of the Marine Biological Association of the UK, 87, 119-128.

Schaefer, H.-C., Jetz, W., \& Böhning-Gaese, K. (2008) Impact of climate change on migratory birds: community reassembly versus adaptation. Global Ecology and Biogeography, 17, 38-49.

Schiavini, A., Goodall, R.N.P., Lescrauwaet, A.-K., \& Alonso, M.K. (1997). Food habits of the Peale's dolphin, Lagenorhynchus australis; review and new information. Report of the International Whaling Commission, 47, 827-834.

Sepúlveda, M., Arismendi, I., Soto, D., Jara, F., \& Farias F. (2013). Escaped farmed salmon and trout in Chile: incidence, impacts, and the need for an ecosystem view. Aquaculture Environment Interactions, 4, 273-283.

Sepúlveda, M., \& Oliva, D. (2005). Interactions between South American sea lions Otaria flavescens (Shaw) and salmon farms in southern Chile. Aquaculture Research, 36, 1062-1068.

Silber, G.K., Lettrich, M.D., Thomas, P.O., Baker, J.D., Baumgartner, M., Becker, E.A., ...Waples, R.S. (2017) Projecting marine mammal distribution in a changing climate. Frontiers in Marine Science, 4, 413.

Thompson, P., White, S., \& Dickson, E. (2004). Co-variation in the probabilities of sighting harbor porpoises and bottlenose dolphins. Marine Mammal Science, 20, 322-328.

Viddi, F.A., Harcourt, R.G., \& Hucke-Gaete, R. (2015). Identifying key habitats for the conservation of Chilean dolphins in the fjords of southern Chile. Aquatic Conservation: Marine and Freshwater Ecosystems, 23, 506-516.

Viddi, F.A., Hucke-Gaete, R., Torres-Florez, J.P., \& Ribeiro, S. (2010). Spatial and seasonal variability in cetacean distribution in the fjords of northern Patagonia, Chile. ICES Journal of Marine Science, 67, 959-970.

Vila, A.R., Falabella, V., Gálvez, M., Farías, A., Droguett, D., \& Saavedra, B. (2016). Identifying high-value areas to strengthen marine conservation in the channels and fjords of the southern Chile ecoregion. Oryx, 50, 308-316.

Watson-Capps, J.J., \& Mann, J. (2005). The effects of aquaculture on bottlenose dolphin (Tursiops sp.) ranging in Shark Bay, Western Australia. Biological Conservation, 124, 519-526.

Wilson, B., Reid, R.J., Grellier, K., Thompson, P.M., \& Hammond, P.S. (2004). Considering the temporal when managing the spatial: a population range expansion impacts protected areas-based management for bottlenose dolphins. Animal Conservation, 7, 331-338.

Wirsing, A.J., Heithaus, M.R., Frid, A., \& Dill, L.M. (2008). Seascapes of fear: evaluating sublethal predator effects experienced and generated by marine mammals. Marine Mammal Science, 24, 115. 
Wisniewska, D.M., Johnson, M., Teilmann, J., Rojano-Doñate, L., Shearer, J., Sveegaard, S., ... Madsen, P.T. (2016). Ultra-high foraging rates of harbor porpoises make them vulnerable to anthropogenic 766 disturbance. Current Biology, 26, 1441-1446.

Wood, S. (2006). Generalized Additive Models: An Introduction with R. Chapman \& Hall/CRC.

768

Zamorano-Abramson, J., Gibbons, J., \& Capella, J. (2010). Diversity and summer distribution of 769 cetaceans in inlet waters of Northern Aisén, Chile. Anales Instituto Patagonia (Chile), 38, 151-157. 


\section{TABLES}

Table 1. Environmental, spatial and temporal variables measured during boat surveys and considered as candidate predictors in the modelling.

\begin{tabular}{|c|c|c|c|c|}
\hline Variable & Working name & Description & $\begin{array}{l}\text { Measurement } \\
\text { method }\end{array}$ & Unit \\
\hline Depth & Depth & Water depth & $\begin{array}{l}\text { Hand-held depth } \\
\text { sounder }\end{array}$ & $\mathrm{m}$ \\
\hline $\begin{array}{l}\text { Distance to } \\
\text { shore }\end{array}$ & ShoreDist & $\begin{array}{l}\text { Linear distance to } \\
\text { nearest shore }\end{array}$ & $\begin{array}{l}\text { Laser range finder } \\
(<1,000 \mathrm{~m}) \& \mathrm{GIS} \\
(\geq 1,000 \mathrm{~m})\end{array}$ & $m$ \\
\hline $\begin{array}{l}\text { Distance to } \\
\text { river }\end{array}$ & RiverDist & $\begin{array}{l}\text { Distance (linear or } \\
\text { alongshore) to nearest } \\
\text { permanent river } \\
\text { mouth }\end{array}$ & GIS & $\mathrm{m}$ \\
\hline Water clarity & WaterClar & Water clarity & Secchi disk depth & $\mathrm{m}$ \\
\hline $\begin{array}{l}\text { Sea surface } \\
\text { temperature }\end{array}$ & SST & $\begin{array}{l}\text { Sea surface } \\
\text { temperature at } 1 \mathrm{~m} \\
\text { depth }\end{array}$ & $\begin{array}{l}\text { Digital } \\
\text { conductivity- } \\
\text { temperature } \\
\text { meter }\end{array}$ & ${ }^{\circ} \mathrm{C}$ \\
\hline Salinity & Salinity & Salinity at $1 \mathrm{~m}$ depth & $\begin{array}{l}\text { Digital } \\
\text { conductivity- } \\
\text { temperature } \\
\text { meter }\end{array}$ & $\%$ \\
\hline $\begin{array}{l}\text { Distance to } \\
\text { shellfish farm }\end{array}$ & ShellfishFarm & $\begin{array}{l}\text { Linear distance to } \\
\text { nearest shellfish farm }\end{array}$ & $\begin{array}{l}\text { Laser range finder } \\
(<1,000 \mathrm{~m}) \& \mathrm{GIS} \\
(>1,000 \mathrm{~m})\end{array}$ & $m$ \\
\hline $\begin{array}{l}\text { Distance to } \\
\text { salmon farm }\end{array}$ & SalmonFarm & $\begin{array}{l}\text { Linear distance to } \\
\text { nearest salmon farm }\end{array}$ & $\begin{array}{l}\text { Laser range finder } \\
(<1,000 \mathrm{~m}) \text {, } \\
\text { random value } \\
\text { from } 1000 \mathrm{~m} \text { to } \\
7000 \mathrm{~m}\end{array}$ & $\mathrm{~m}$ \\
\hline Beaufort scale & SeaCond & Sea conditions & Field observation & - \\
\hline $\begin{array}{l}\text { Latitude / } \\
\text { Longitude }\end{array}$ & LatLon & $\begin{array}{l}\text { Geographic position } \\
\text { expressed in decimal } \\
\text { degrees }(-N,-E)\end{array}$ & $\begin{array}{l}\text { Hand-held Garmin } \\
\text { GPS receiver }\end{array}$ & $\circ$ \\
\hline Year & Year & $\begin{array}{l}\text { Year in which research } \\
\text { was carried out }\end{array}$ & & - \\
\hline
\end{tabular}


Table 2. Environmental models based on forward stepwise selection. Covariates are shown in order of importance and sequential entry into the model. Effective degrees of freedom for each smooth are given in the 'edf' column. The \% Dev shows the contribution of each term to the explained deviance. $\triangle \mathrm{AIC}$ is the reduction of AIC when the covariate was added to the model.

\begin{tabular}{lccc}
\multicolumn{4}{c}{ Chilean dolphin } \\
\hline Smooth & edf & \% Dev & A AIC \\
\hline$s$ (ShoreDist) & 1.9 & 17.8 & \\
\hline$s$ (ShellfishFarm) & 2.0 & +4.8 & -89.7 \\
\hline$s$ (Depth) & 2.4 & +2.6 & -49.5 \\
\hline$s$ (WaterClar) & 3.5 & +2.5 & -42.5 \\
\hline$s$ (RiverDist) & 3.8 & +1.9 & -32.1 \\
\hline$s$ (SST) & 3.9 & +1.3 & -18.0 \\
\hline$s$ (SeaCond) & 1.7 & +1.0 & -17.4 \\
\hline$s$ (SalmonFarm) & 3.2 & +0.9 & -10.3 \\
\hline$s$ (Salinity) & 1.0 & +0.4 & -7.7 \\
\hline Total & & $\mathbf{3 3 . 2}$ & \\
\hline
\end{tabular}

\begin{tabular}{lccc}
\multicolumn{4}{c}{ Peale's dolphin } \\
\hline Smooth & edf & \% Dev & A AIC \\
\hline $\mathrm{s}$ (Depth) & 3.6 & 8.5 & \\
\hline $\mathrm{s}$ (ShellfishFarm) & 3.0 & +2.2 & -29.2 \\
\hline $\mathrm{s}$ (ShoreDist) & 2.8 & +1.4 & -16.9 \\
\hline $\mathrm{s}$ (RiverDist) & 3.7 & +1.6 & -16.8 \\
\hline $\mathrm{s}$ (Salinity) & 2.1 & +1.1 & -14.1 \\
\hline $\mathrm{s}$ (SST) & 2.1 & +0.7 & -6.8 \\
\hline $\mathrm{s}$ (SeaCond) & 2.1 & +0.6 & -5.4 \\
\hline Total & & $\mathbf{1 6 . 1}$ &
\end{tabular}




\section{FIGURES (legends)}

Figure 1. Distribution of sightings and absence sampling points in the northern and southern study areas in the Chiloé archipelago, southern Chile. Red points: Chilean dolphins; Yellow points: Peale's dolphins. Small blue points: sampling locations without dolphins (absences). Light blue area: extent of the coastal survey areas. Inset: Location of Chiloé archipelago in South America.

Figure 2. Occurrence of Chilean dolphins as a smooth function of covariates: distance to shore, distance to nearest river, depth, water clarity, salinity, SST, distance to nearest shellfish farm and distance to nearest salmon farm. Shaded areas represent $95 \% \mathrm{Cl}$. Data points are represented as rug plots on the horizontal axes.

Figure 3. Predicted mean occurrence of Chilean dolphins (a) and Peale's Dolphins (d) in the the southern study area, together with upper (b, e) and lower (c, f) $95 \% \mathrm{Cl}$.

Figure 4. Predicted mean occurrence of Chilean dolphins (a) and Peale's Dolphins (d) in the northern study area, together with upper (b, e) and lower (c, f) $95 \% \mathrm{Cl}$.

Figure 5. Occurrence of Peale's dolphins as a smooth function of different covariates: depth, distance to shore, salinity, SST, distance to nearest river and distance to nearest shellfish farm. Shaded areas represent $95 \% \mathrm{Cl}$. Data points are represented as rug plots on the horizontal axes.

Figure 6. Predicted mean dolphin occurrence of Chilean and Peale's dolphins overlaid with concessions for salmon and shellfish farms in 2015 in the southern (a) and northern (b) study areas. For details on the colour scheme for predicted occurrence see Figures 3 and 4. 


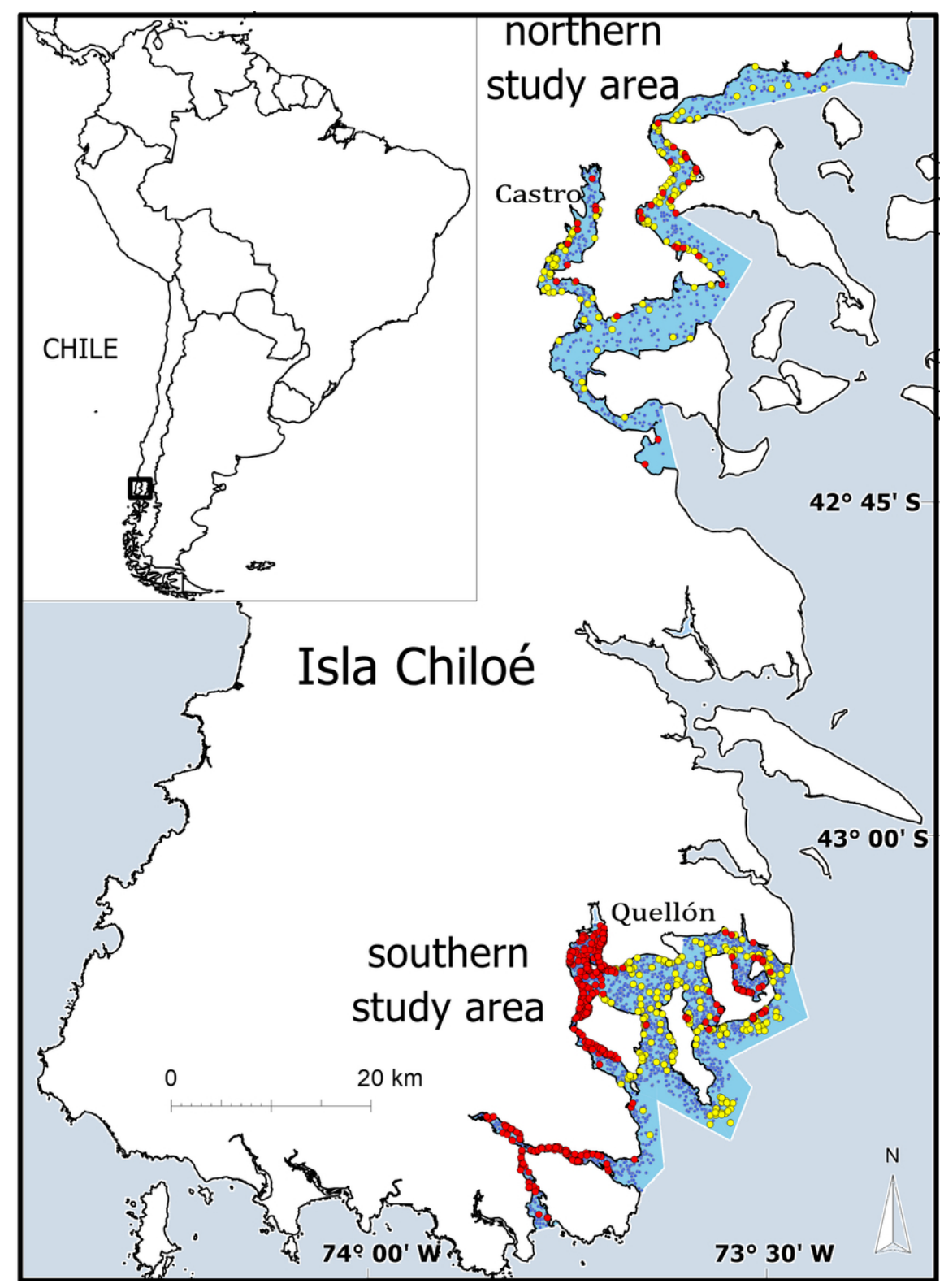

$75 \times 103 \mathrm{~mm}(300 \times 300$ DPI $)$ 

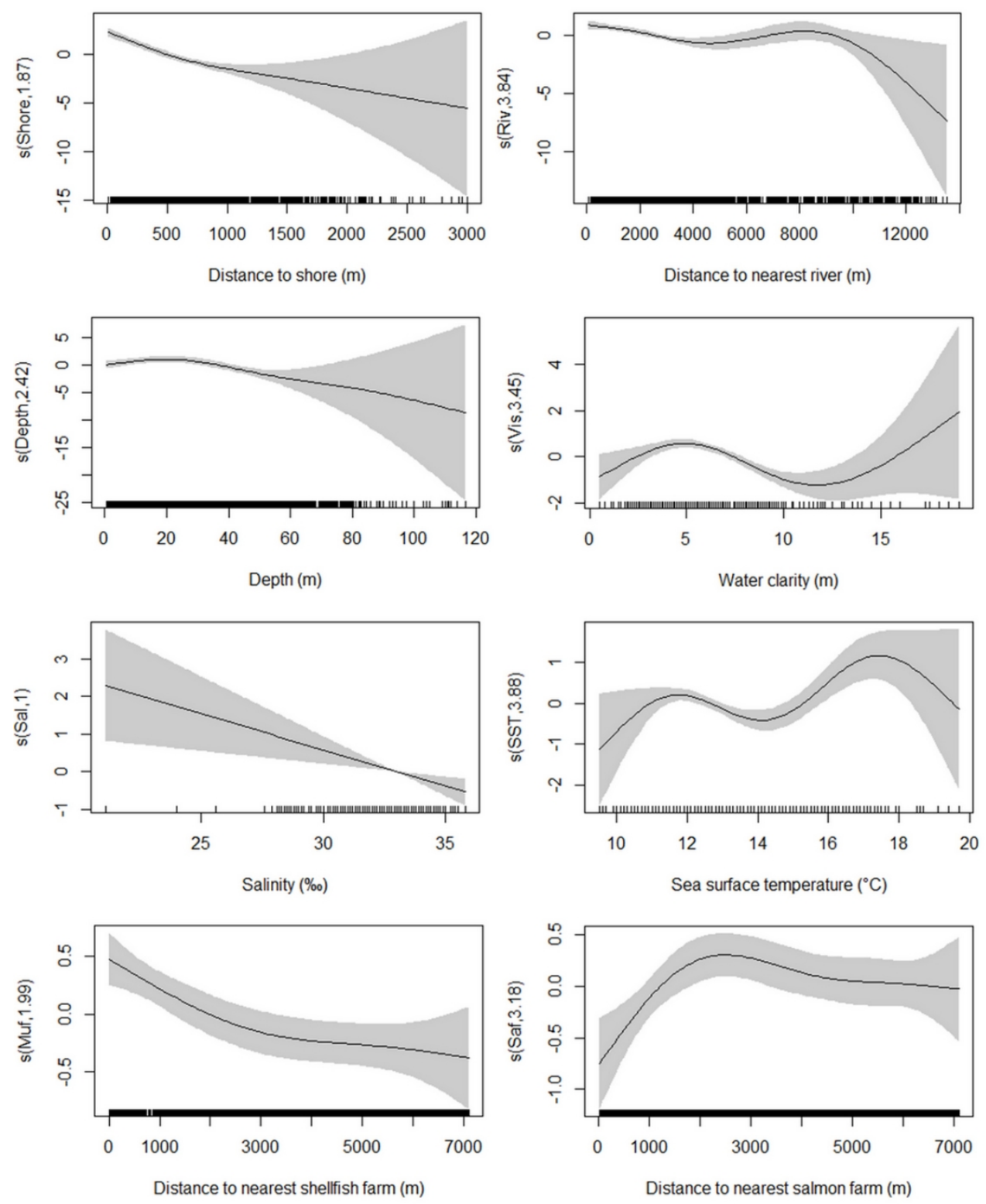

$99 \times 123 \mathrm{~mm}(300 \times 300$ DPI $)$ 


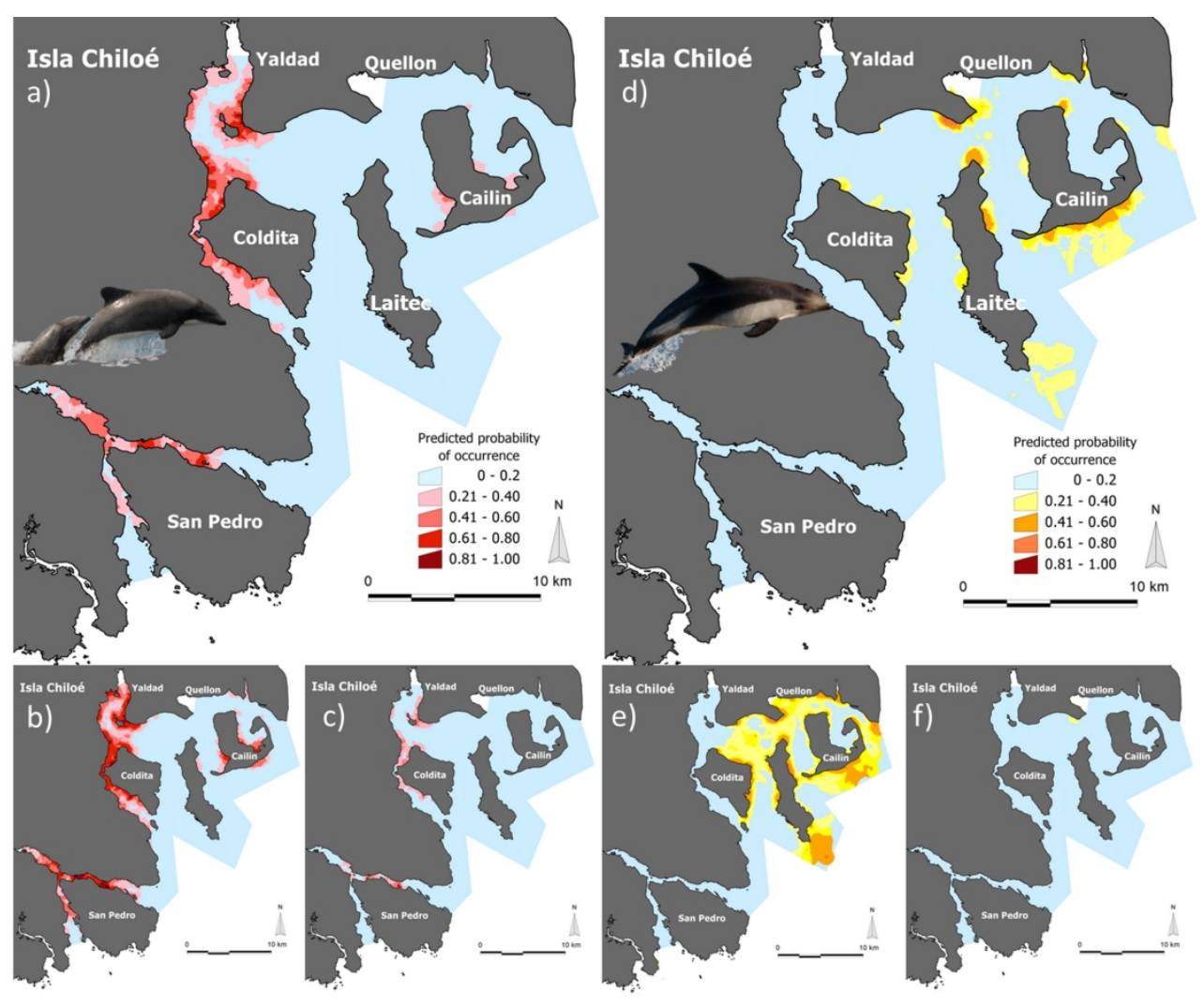

$399 \times 321 \mathrm{~mm}(150 \times 150 \mathrm{DPI})$ 


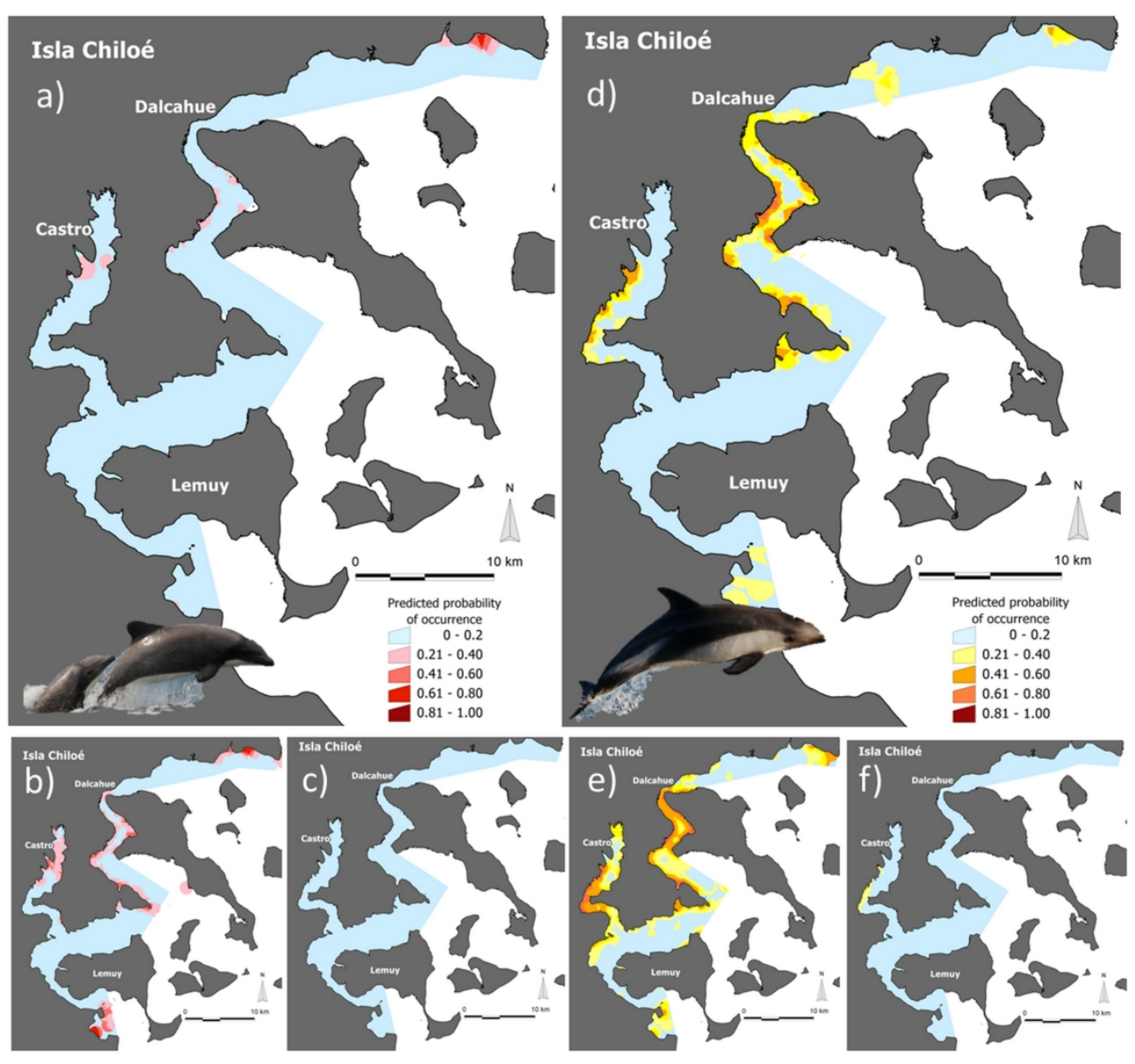

$199 \times 185 \mathrm{~mm}(300 \times 300 \mathrm{DPI})$ 

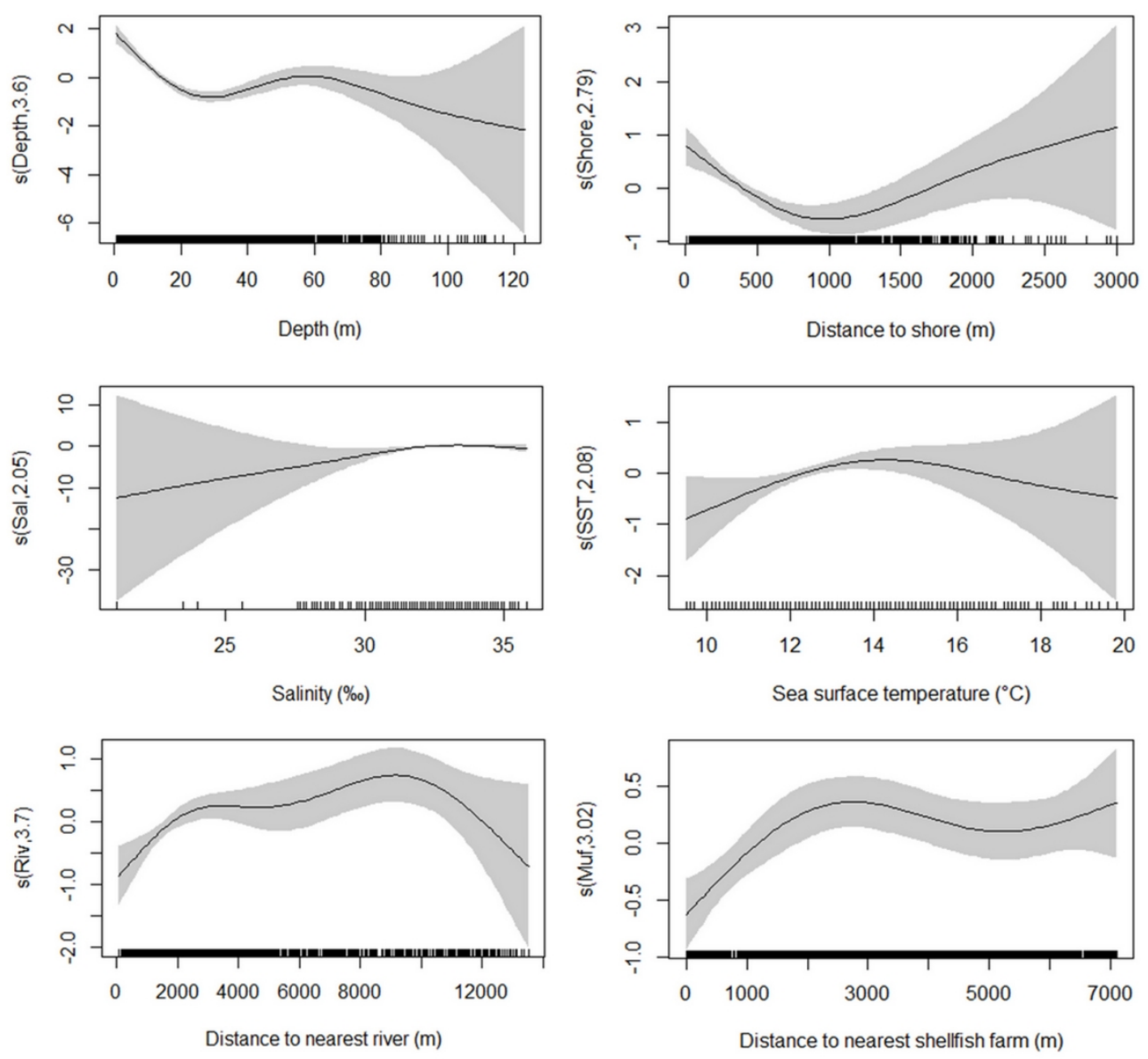

$119 \times 111 \mathrm{~mm}(300 \times 300$ DPI $)$

http://mc.manuscriptcentral.com/aqc 


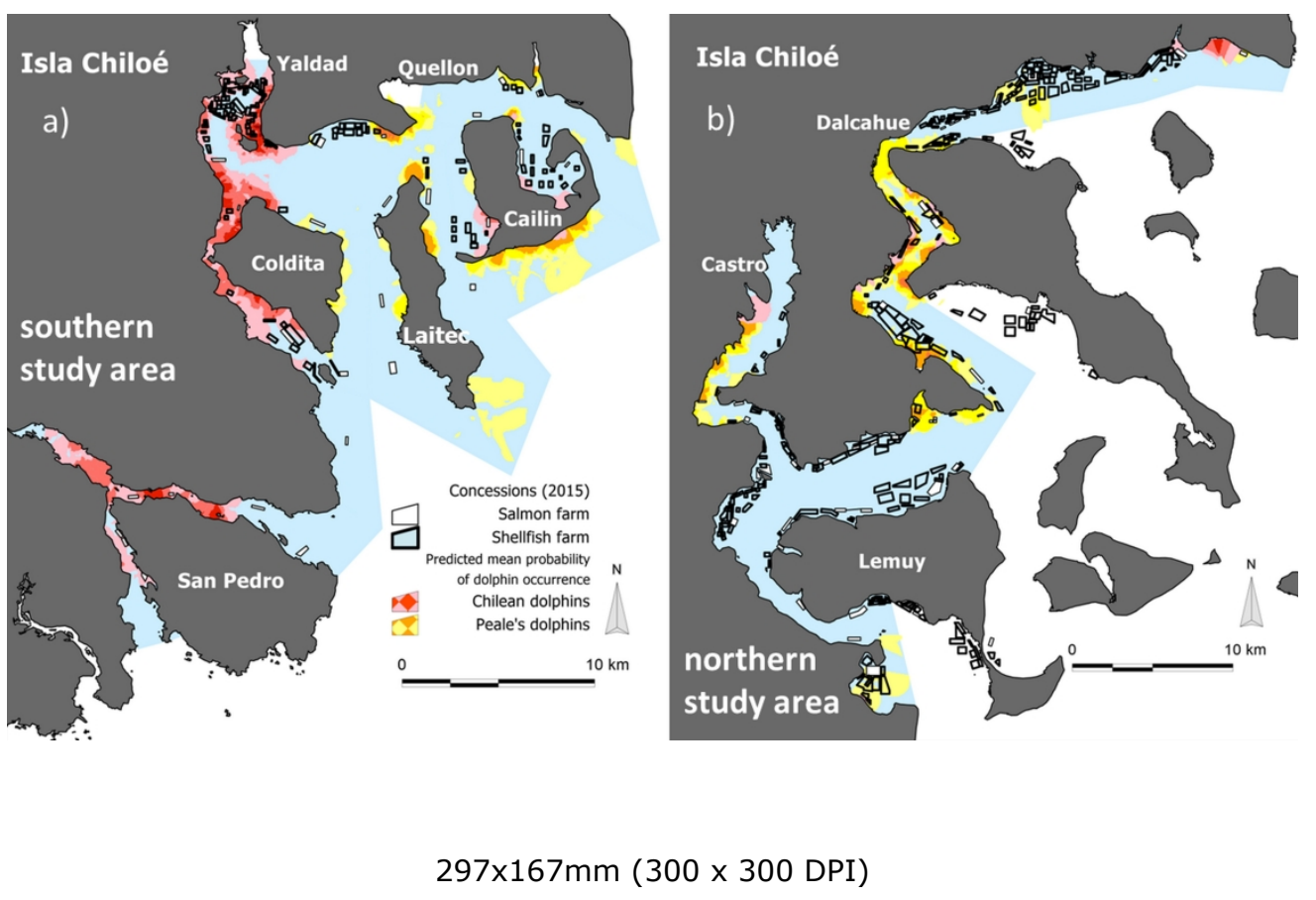

http://mc.manuscriptcentral.com/aqc 